AperTO - Archivio Istituzionale Open Access dell'Università di Torino

\title{
Mapping meanings of personalisation
}

\section{This is the author's manuscript}

Original Citation:

\section{Availability:}

This version is available http://hdl.handle.net/2318/123139

since 2016-01-12T22:56:24Z

Publisher:

Sense Publishers

Terms of use:

Open Access

Anyone can freely access the full text of works made available as "Open Access". Works made available under a Creative Commons license can be used according to the terms and conditions of said license. Use of all other works requires consent of the right holder (author or publisher) if not exempted from copyright protection by the applicable law. 
Personalisation of Education in Contexts 
COMPARATIVE AND INTERNATIONAL EDUCATION:

A Diversity of Voices

Volume 18

Series Editors

Allan Pitman

University of Western Ontario, Canada

Vandra Masemann

University of Toronto, Canada

Miguel A. Pereyra

University of Granada

Editorial Board

Mark Bray, International Institute for Educational Planning, Paris, France

Ali Abdi, University of Alberta, Canada

Christine Fox, University of Wollongong, Australia

Steven Klees, University of Maryland, USA

Nagwa Megahed, Ain Shams University, Egypt

Crain Soudien, University of Cape Town, South Africa

David Turner, University of Glamorgan, England

Medardo Tapia Uribe, Universidad Nacional Autónoma de Mexico

\section{Scope}

Comparative and International Education: A Diversity of Voices aims to provide a comprehensive range of titles, making available to readers work from across the comparative and international education research community. Authors will represent as broad a range of voices as possible, from geographic, cultural and ideological standpoints. The editors are making a conscious effort to disseminate the work of newer scholars as well as that of well-established writers. The series includes authored books and edited works focusing upon current issues and controversies in a field that is undergoing changes as profound as the geopolitical and economic forces that are reshaping our worlds. The series aims to provide books which present new work, in which the range of methodologies associated with comparative education and international education are both exemplified and opened up for debate. As the series develops, it is intended that new writers from settings and locations not frequently part of the English language discourse will find a place in the list. 


\section{Personalisation of Education in Contexts}

Policy Critique and Theories of Personal Improvement

Edited by

Monica E. Mincu

University of Turin, Italy

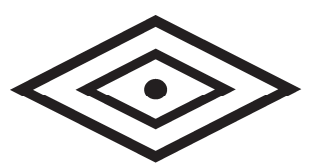

SENSE PUBLISHERS

ROTTERDAM/BOSTON/TAIPEI 
A C.I.P. record for this book is available from the Library of Congress.

ISBN: 978-94-6209-026-2 (paperback)

ISBN: 978-94-6209-027-9 (hardback)

ISBN: 978-94-6209-028-6 (e-book)

Published by: Sense Publishers,

P.O. Box 21858,

3001 AW Rotterdam,

The Netherlands

https://www.sensepublishers.com/

Printed on acid-free paper

Picture taken on February 15, 2012 by Emeritus Professor Yukitsugu Kato at the Ooyaguti Elementary School, an open-space school (Ooyaguti-Kitamachi, Itabashi-Ku, Tokyo). A Math lesson of two 2nd classes together: "Triangle and Square". A team teaching and "my pace learning" lesson.

All Rights Reserved (C) 2012 Sense Publishers

No part of this work may be reproduced, stored in a retrieval system, or transmitted in any form or by any means, electronic, mechanical, photocopying, microfilming, recording or otherwise, without written permission from the Publisher, with the exception of any material supplied specifically for the purpose of being entered and executed on a computer system, for exclusive use by the purchaser of the work. 



\section{TABLE OF CONTENTS}

Foreword: Personalisation is Political, but What Kind of Politics?

Mark Ginsburg

Editorial Introduction

xiii

Monica E. Mincu

Part 1: Personalisation, School Change and (Personal) Improvement

1. Personalisation and the Classroom Context Chris Watkins

2. Breakthrough: Deepening Pedagogical Improvement Michael Fullan

3. Personalisation: Integrating the Personal with the Public in A Pedagogy for Social Sustainability Ruth Deakin-Crick

Part 2: Contrasting Readings on Personalisation: A Governance Policy Critique Versus Socially Embedded Pedagogies

4. The Challenge of Personalisation for Tomorrow's Schools:

An Overview

Giorgio Chiosso

5. The Habit as a Means to Personalise Teaching

Concepción Naval and Dolores Conesa

6. Personalisation, Education, Democracy and the Market Michael Fielding

7. Personalisation, Personalised Learning and the Reform of Social Policy: Prospect for Molecular Governance in the Digitised Society Michael A. Peters

\section{Part 3: Politics and Contexts of Personalisation}

8. Personalisation of Education: Reflections from an International Perspective

Ferran Ferrer

9. Personalisation and Education in China

Baocun Liu and Qian He 


\section{TABLE OF CONTENTS}

10. What is Personalised Learning in England? An investigation of teacher's conceptions Ikumi Courcier

11. Personalised Learning in Japan

Ikumi Courcier and Masahiro Nasu

12. The Personalisation of Learning - Between Reality and Desideratum in the Romanian Education System Irina Horga

13. Mapping Meanings of Personalisation Monica E. Mincu

Notes on Contributors

Index 
MONICA E. MINCU

\section{MAPPING MEANINGS OF PERSONALISATION}

\section{DEEPENING THEORIES OF PERSONALISATION}

Trying to engage with personalisation is not an easy task, given the prevalence of its shifting culturally and historically bounded meanings. The historical roots of a personalistic approach in education and in the teacher education field, as opposed to academic, competency, and social recontructionist approaches, lie in the child study movement initiated by Stanley Hall. A personalist as fundamentally developmentalist approach was focused principally on the stages of child development. Building on humanistic ideas, this approach maintained that child development is the most significant basis for deciding what should be taught. From the outset, in this perspective there is no learning outcome standardisation. As Grow-Maienza (1996) argues, '[t]he focus is instead on coming to terms with self, acquiring knowledge of the stages of child development, and demonstrating an empathetic relationship with students more as equals than in an authoritarian role' (p. 511).

A first decisive element is whether personalisation is seen as a version of, compatible with, or as built upon individualisation as a key component. Personalisation is explicitly seen as synonymous with individualisation, or even differentiation, as defined by Tomlinson (1998) and Fullan (in this volume), in association with two other main ingredients, precision and professional learning. Ferrer (in this volume) maintains it is based on two main pillars: individualisation and socialisation. The prominent Japanese scholar, Kato, associates the two concepts as follows: individualised instruction and personalised learning, and suggests their conceptual pertinence in relation to teaching versus learning (Courcier \& Nasu, 2011). For other scholars, such as Chris Watkins (2004; in this volume), Michael Fielding (2008, in this volume), and Giorgio Chiosso (in this volume), personalisation has nothing to do with individualisation. For them the accent is on a 'community dimension', in the form of a 'personalised community classroom' for Watkins, or as democratic fellowship and radical collegiality for Fielding.

Some of the main theoretical perspectives of the authors who actively engage with personalisation deal with positivist strands such as the school efficacy movement (large-scale school improvement for Fullan), the learning communities perspective, philosophical-personalist and communitarian readings, such as those of Chiosso, Fielding, Naval and Conesa (in this volume) and also critical approaches such as those of Fielding (2008) and Deakin-Crick (in this volume). However, a crucial issue is how these authors conceive of teacher professionalism, as scripted or unscripted, and how they relate to the standards issue. A significant 
group of scholars supports the thesis of an unscripted professionalism, a curriculum free of standards and evaluation domains (Watkins, Deakin-Crick, Fielding, in this volume), as a clear prevalence of the personal versus the functional. Other scholars, such as Fullan and Chiosso (in this volume), argue for a non-dichotomist view.

Another important indicator is whether personalisation is conceived as universal approach, or if it is explicitly targeted to particular pupil categories. For most scholars, is must be universal and particularly beneficial to the lowest achievers. Some scholars maintain that it has emerged in relation to developing education strategies for the disabled in mainstream schools (Courcier, 2011). In this case, it has to do with the teacher's ability to teach in a heterogeneous classroom. A comparativist such as Ferrer (in this volume) also supports this view and considers it as a strategy for dealing with heterogeneous settings, and especially pupils from immigrant origins. Therefore, personalisation becomes very much in line with a teaching in/for diversity paradigm. This emphasis on the teaching dimension is not, however, the prevalent view. For most scholars, it should involve both the teaching and learning processes, the pupils' responsibility for their own learning and the teacher's responsibility for both teaching and learning.

Assessing personalisation as a teaching versus learning approach and its scope, whether universalist or aimed at specific groups of pupils - the gifted and the highest versus the lowest achievers - raises a fundamental issue of equity. When responsibility is foremost imagined in terms of the pupils' responsibility to make relevant choices for their own learning, then it is clear that disadvantaged pupils may be further pushed to the margins. Promoting excellence while helping the lowest achievers to make significant progress cannot just be declared as compatible or not. Instead it requires sound empirical investigation. A relevant question is whether accelerated learning programs might help both the lower and the higher achievers to improve their learning results.

A key concept in personalisation is the emphasis on 'fostering diversity' in each child, as interpreted by Howard Gardner (1997) from his multiple intelligences theory perspective. This concept updates an earlier developmentalist understanding in two ways: the individual-centred school, and the focus on learning and teaching styles. In fact, the learning style concept, which builds on the cognitive ideas of Allport (1924), emerged in response to multiple intelligence theory and referred to a notion of 'diversity in education' (Ducette, Sewell, \& Poliner Shapiro, 1996). A transversal and crucial notion of diversity in education implies therefore more than ethnic and cultural diversity. Rather, it includes all subject-related differences which are relevant in the learning process. Hence, personal and learning diversity of pupils requires differential treatment and the mastering of several teaching styles. A synthetic overview of some of the major theories is offered in Table 1. 
Table 1.

\begin{tabular}{|c|c|c|c|}
\hline & Michael Fullan & Chris Watkins & Michael Fielding \\
\hline 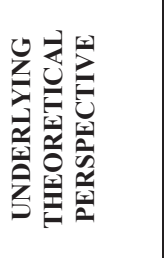 & \begin{tabular}{|l} 
Large-scale school \\
improvement \\
It is about individuals, but \\
it is relational-between \\
the teacher, the student, \\
the home and the school.
\end{tabular} & $\begin{array}{l}\text { Learning } \\
\text { communities } \\
\text { (collective } \\
\text { understanding) }\end{array}$ & $\begin{array}{l}\text { A governance matter in England } \\
\text { (in line with Hartley, Peters) } \\
\text { A personalist tradition needed } \\
\text { (Macmurray) } \\
\text { We enter into personal relation } \\
\text { with others because it is through } \\
\text { them that we can be and become } \\
\text { ourselves. }\end{array}$ \\
\hline 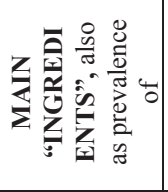 & $\begin{array}{l}\text { Breakthrough Theory: } \\
\text { Personalisation/Individu } \\
\text { ali-sation. } \\
\text { Precision } \\
\text { Professional learning } \\
\end{array}$ & $\begin{array}{l}\text { The personalised } \\
\text { community } \\
\text { classroom }\end{array}$ & $\begin{array}{l}\text { Prefigurative practice based on } \\
\text { democratic experimentalism } \\
\text { Radical curriculum Enabling } \\
\text { assessment }\end{array}$ \\
\hline 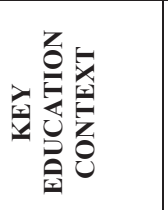 & Classroom \& school & Classroom & Classroom \& school \\
\hline$\underset{\substack{Z \\
\hdashline}}{\substack{Z \\
\hdashline}}$ & Learning \& teaching & $\begin{array}{l}\text { Learning: } \\
\text { knowledge as a joint } \\
\text { enterprise } \\
\text { Teachers operate } \\
\text { differently }\end{array}$ & No explicit assumption \\
\hline 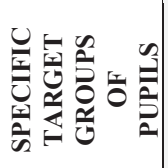 & $\begin{array}{l}\text { Universal } \\
\text { It must be universal-for } \\
\text { all -or it will fail. }\end{array}$ & $\begin{array}{l}\text { (Implicitly) } \\
\text { Universal }\end{array}$ & $\begin{array}{l}\text { Universal - a matter of inclusive } \\
\text { identities. }\end{array}$ \\
\hline 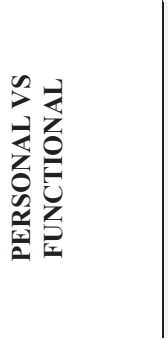 & $\begin{array}{l}\text { BOTH } \\
\text { Professional learning for } \\
\text { teachers in their contexts } \\
\text { The standards are relevant } \\
\text { and must be } \\
\text { communicated to the } \\
\text { students }\end{array}$ & $\begin{array}{l}\text { PERSONAL } \\
\text { Unscripted } \\
\text { professionalism } \\
\text { Radical questioning } \\
\text { of the role of the } \\
\text { teacher, the } \\
\text { importance of } \\
\text { standards and tests } \\
\text { and of the prescripted } \\
\text { curriculum }\end{array}$ & $\begin{array}{l}\text { PERSONAL - as democratic } \\
\text { fellowship } \\
\text { Unscripted professionalism } \\
\text { Radical collegiality } \\
\text { Keep options open, no reference to } \\
\text { standards is required. }\end{array}$ \\
\hline
\end{tabular}

\section{PERSONALISATION POLITICS AND POLICY TALK}

Different types of personalisation politics on paper and different degrees of their practical development are immediately visible if we look at some contexts as in the 
Table 2. The English context is one of the most visible nationally and well-known internationally, greatly contributing to consolidating and disseminating the personalisation concept. Other contexts where there is some policy talk and piecemeal politics are the Australian State of Victoria and the United States. However, significant differences are clear as to what counts as personalisation and in the degrees of policy implementation.

Engaging with policies and their meanings from a comparative perspective lies at the very heart of the comparative education field. At the same time, it is not clear-cut and remains a contested area of scholarship. From a rationalist perspective, we can distinguish between policies as product and as process. From a conflict perspective, policy analysis is principally concerned with the prevalence of actors' interests at a national level, and with the global-local hybridisation dynamic in dealing with the dominance of Anglo-American scholarship over indigenous knowledge.

In this case, I distinguish between written policies as evidenced by official key documents or legal instruments and the 'policy talk' as represented by relative scholarship upholding the official view in several national contexts. Another relevant level is, in Yang's (2007) words, the level of how 'practitioners interpret policy with their own histories, experiences, values and purposes' (p. 250). A diversity of meanings is not only that created by the discrepancy between official policy and policy talk and the actors' own interpretations. Very few scholars engage with this discrepancy, with the exception of Courcier (2007; forthcoming) in the English case.

In fact, from a comparative point of view, the official policy and the policy talk of personalisation are essentially and contextually developed with significantly different meanings in various countries. (see Table 2)

Table 2.

\begin{tabular}{|c|c|c|c|c|c|}
\hline & \multicolumn{3}{|c|}{ On Paper } & \multicolumn{2}{|c|}{ Concrete implementation of the Politics } \\
\hline & $\begin{array}{l}\text { Year of } \\
\text { initiation }\end{array}$ & $\begin{array}{l}\text { Main rationale \& } \\
\text { policy instruments }\end{array}$ & Core concepts & $\begin{array}{c}\text { Grade of } \\
\text { development }\end{array}$ & Practical configurations \\
\hline 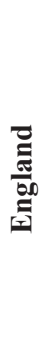 & 2003 & $\begin{array}{l}\text { General approach to } \\
\text { learning \& teaching } \\
\text { DfES. } \\
\text { DfES documents } \\
\text { (see Courcier) }\end{array}$ & $\begin{array}{l}\text { Assessment for } \\
\text { learning; } \\
\text { Teaching and learning } \\
\text { strategies that stretch } \\
\text { pupils; } \\
\text { Curriculum } \\
\text { entitlement and } \\
\text { choice; } \\
\text { Student-centred } \\
\text { organizations; } \\
\text { Partnership beyond the } \\
\text { school }\end{array}$ & $\begin{array}{l}\text { Officially } \\
\text { promoted policy }\end{array}$ & $\begin{array}{l}\text { Confusing practices of } \\
\text { ability grouping and mixed- } \\
\text { ability groping, accelerated } \\
\text { learning programs with } \\
\text { universalist scope } \\
\text { (Courcier, 2007 } \\
\text { Paradoxes - Fielding) }\end{array}$ \\
\hline
\end{tabular}




\begin{tabular}{|c|c|c|c|c|c|}
\hline 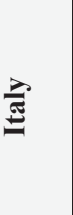 & $\begin{array}{l}2003- \\
2009 / 2010\end{array}$ & $\begin{array}{l}\text { General approach to } \\
\text { learning \& teaching } \\
\text { - National Curriculum } \\
\text { - Orientations for } \\
\text { Personalised Plans of } \\
\text { Instructions }\end{array}$ & $\begin{array}{l}\text { Pupil as a person; } \\
\text { School as community; } \\
\text { Practical strategies: } \\
\text { PSP } \\
\text { Personalist } \\
\text { philosophical tradition }\end{array}$ & $\begin{array}{l}\text { Limited to the } \\
2003-2009 \\
\text { period of time. }\end{array}$ & $\begin{array}{l}\text { Different \& confusing } \\
\text { practices: } \\
\text { Minimum. standards } \\
\text { pathway for lower achievers } \\
\text { (with parents agreement) } \\
\text { Personalised curriculum but } \\
\text { standardised evaluation }\end{array}$ \\
\hline 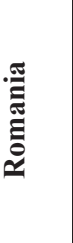 & NA & $\begin{array}{l}\text { A specific issue: the } \\
\text { inclusion of disabled } \\
\text { pupils into mainstream } \\
\text { classes }\end{array}$ & $\begin{array}{l}\text { Individualisation } \\
\text { Differentiation; } \\
\text { Differentiated } \\
\text { treatment }\end{array}$ & $\begin{array}{l}\text { Increasing } \\
\text { awareness } \\
\text { limited to the } \\
\text { field of disabled } \\
\text { pupils }\end{array}$ & $\begin{array}{l}\text { Mainstream inclusion of } \\
\text { disabled pupils. } \\
\text { Still separated settings on } \\
\text { ethnical bases. } \\
\text { Group learning, alternated } \\
\text { with frontal teaching and } \\
\text { individual learning } \\
\text { predominates }\end{array}$ \\
\hline 纪 & NA & $\begin{array}{l}\text { General approach to } \\
\text { learning \& teaching }\end{array}$ & $\begin{array}{l}\text { Student-centred } \\
\text { approaches }\end{array}$ & $\begin{array}{l}\text { Limited } \\
\text { territorially }\end{array}$ & Some experiments \\
\hline$\underset{\mathscr{S}}{\mathscr{\omega}}$ & NA & $\begin{array}{l}\text { General approach to } \\
\text { learning \& teaching } \\
\text { - NASSP }(1996,2004)\end{array}$ & $\begin{array}{l}\text { Personalising the } \\
\text { learning environment; } \\
\text { Creating smaller } \\
\text { learning communities } \\
\text { (building upon more } \\
\text { consolidated } \\
\text { approaches of } \\
\text { differentiation + } \\
\text { assessment for } \\
\text { learning) }\end{array}$ & $\begin{array}{l}\text { Some policy } \\
\text { recommendation } \\
\mathrm{s}, \\
\text { limited } \\
\text { territorially; }\end{array}$ & $\begin{array}{l}\text { Some documented practices, } \\
\text { great variety of initiatives }\end{array}$ \\
\hline
\end{tabular}

\section{English, American and Australian ideas of Personalisation}

A brief look at personalisation policy and policy talk in these three countries may reveal different meanings, 'ingredients' or core concepts and possible directions. We can notice personalisation recontextualisations, more or less socially or individually orientated, more or less social justice versus system efficiency oriented (see table also).

The English case has been amply debated throughout the volume and assessed as definitively ambiguous. It emerges however that personalisation is a learning style including five elements (Campbell et al., 2007, p. 140), such as assessment for learning, teaching and learning strategies that stretch pupils, curriculum entitlement and choice, student-centred organisations and partnership beyond the school.

A major ambiguity of the English policy of personalisation is related to its target group - more advantaged pupils in terms of social class - and related social equity issues. As Campbell et al. (2007) noted:

[m]oreover, self-motivation and self-regulation, not to mention educational progress, however desirable intrinsically, are not equally distributed among different classes and cultures in English society, so to ambiguity is added the possibility of continuing, or even increased, educational disadvantage (pp. 138-139). 
The proposed solution is a redistribution of resources in order to "not widen inequalities' (Leadbeater in Campbell et al., 2007, p. 139). Notwithstanding, this solution is obviously 'not the same as reducing them, and could be read as implying that personalisation does not embody an ambition to redress the sources of inequality in educational achievement or even educational provision' (Campbell et al., 2007, p. 139). For David Hopkins, there is complete compatibility between the aim of promoting excellence and that of supporting the most disadvantaged and at risk students:

It's building schooling around the needs and aptitudes of individual pupils, shaping teaching around the way different youngsters learn. It's also about making sure that the talent of each pupil is supported and encouraged, and about personalising the school experience to enable pupils to focus on their learning ... personalised learning has to be a system-wide achievement so that it impacts on every student in every school (Campbell et al., 2007, p. 142).

In the American education, Clarke (2003) maintains that already by 1996 in response to "the need to enliven large, comprehensive high schools, the National Association of Secondary School Principals (NASSP) publicised the need for high school personalisation' (p. 18). The report Breaking Ranks: Changing an American Institution recommended ways to personalise the high school experience for each enrolled student, which inspired Maine, Vermont, and Rhode Island policy recommendations to 'abolish anonymity' in their schools. A crucial requirement is school size, which must not exceed six hundred students, in order to promote a sense of community and belonging. Pilar argues that this report relaunched previous analyses such as those of Sizer (Horace's Compromise, 1984), the Coalition of Essential Schools (1984), A Nation at Risk (1983) and the Carnegie Foundation report Turning Points: Preparing American youth for the 21st century (1989). The elements of an American idea of personalisation consist in the personalisation of the learning environment, the creation of smaller learning communities and fostering relationships, the generation of positive school climate and the development of effective school leadership. (Pillar, 2007, p. 13)

The crucial role played by the learning environment is clearly stated in a recent NASSP (2004) report entitled What the Research Shows: Breaking Ranks in Action:

Establishing and maintaining that environment implies not only ensuring that external factors support learning, but also providing students with appropriate supportive relationships critical to their intellectual growth, these supportive relationships personalise the educational experience and help identify early warning signs of student trouble-both academically and personal (p. 3).

The table below is revealing of how a wide range of consolidated practices are reframed and recontextualised under the current idea of personalisation. 
Table 3.

\begin{tabular}{ll}
\hline Personal learning plans & Community based learning \\
Service learning & Foxfire classrooms \\
Inclusive practices & MAPS (student action plans) \\
Varied instruction & Portfolios of student work \\
Independent studies/student presentations & Senior projects \\
Career explorations & Community mentoring \\
Applied learning & Extra time and help available from teachers \\
Student choice in courses and class work & Seminar-based instruction/Socratic seminars \\
Teaching and learning teams & Democratic classrooms \\
Flexible scheduling & Small schools \\
Heterogeneous grouping & No bells \\
Small classrooms & No class interruptions \\
Adult/student relationships sustained over & Adults addressed by their first names \\
years & Guidance/teacher partnerships \\
Advisory groups \& parent conferences & Accessible counselling staff \\
Teachers and kids eating together & Home visits \\
Special education available to everyone & Teachers and students as co-learners \\
Community of learners emphasised & Shared mission and goals \\
Community meetings & \\
\hline Clomke,2003, $p .22$ ) & \\
\hline
\end{tabular}

(Clarke, 2003, p. 22)

The American model is plainly focused on the quality of interpersonal relationships, on the school's capacity to organise itself as a community. In addition, a relevant transversal element to different contexts is the personal leaning plan for each student (A Call to Action: Transforming High School for All Youth in Pilar, 2007, pp. 18-19).

The best Australian schools that provide a tailored education combine the following elements (Kelly, 2005 in Keamy, Nicholas, Mahar, \& Herrick, 2007):

- extra small group or one-to-one tuition for those that need it - not as a substitute for excellent whole-class teaching, but as an integrated part of the child's learning;

- opportunities for all children to get extra support and tuition in subjects and activities they are interested in, as well as access to a range of opportunities beyond the school day, including weekend and holiday courses and online learning;

- exciting whole-class teaching, which gets the best from every child setting or grouping children of similar ability and attainment;

- a rich, flexible and accessible curriculum and, for older pupils, one that allows them to mix academic and vocational learning;

- innovative use of ICT, both in the classroom and linking the classroom and home. (p. 13) 
Quite relevant that both ability grouping and whole class teaching - which are contested issues by most scholars of personalisation - are reframed as possible strategies to promote personalisation and equally considered compatible with social justice purposes. In the same vein, choice and flexibility of assessment are needed to promote a student-centred curriculum and sensitive to socioeconomic background of their students.

Cole (2001) categorises student-centred approaches as follows:

- brain-based teaching, problem-based learning or inquiry-based learning: based upon Gardner's theory of multiple intelligences and the idea of the Thinking Curriculum, these approaches centre around deep and challenging learning, rich tasks, problem solving and decision making in authentic situations, high levels of student decision making, a cooperative classroom culture, supportive relationships and assessment as an intrinsic part of the learning experience

- the Authentic Curriculum: exemplified by the Coalition of Essential Schools in the United States and the New Basics project in Queensland, which states that teaching and learning should be personalised to the greatest possible extent, with the teacher acting as a coach for the student's active, self-directed learning

- constructivism: this proposes that teachers tailor instruction to students' needs and interests. It recognises that the more relevance students see in the curriculum and its learning tasks, the more their interest in learning grows. As with the other approaches, it assesses student learning in the context of daily classroom investigations and not through separate formal tests.

This volume mainly engages with contextual reasons and rationalities that lead to a myriad of initiatives which may be fully or partly subsumed by an umbrella "personalisation" idea. The very action of documenting a plurality of theoretical perspectives, cultural and political contexts cannot logically lead to finding or proposing a stable definition. A sociological and comparative endeavour focused on how this issue is understood, its ingredients and meanings, cannot engage at the same time with a normative pedagogical approach and thus cannot offer the reader "the answer" to the question: "what does personalisation really mean?". Much more relevant for me are its conceptual plasticity and political flexibility, which I have attempted to capture through the contributions to this volume, and map in this final chapter. Thus, I will offer in the next section my interpretation from a sociological and comparative perspective, drawing from my contextual experience of the Italian politics of personalisation.

\section{The Italian Case: Personalised Study Plans}

In this section, I will argue that the recent English politics of personalisation received great attention from the Italian public. While individualisation is the preferred alternative for most left-wing pedagogy, personalisation is principally endorsed by Catholic pedagogy, although not exclusively. In fact, on the left-wing side, scholars see it as an equity strategy for those at risk and in line with heterogeneous grouping and cooperative learning. Most scholars read it, however, from a traditionally 
personalist perspective as a person-centred and community-related strategy, with a specific emphasis on personal excellence. Right-wing governments have promoted personalisation since 2003 through various policy documents, although at a somewhat rhetorical-decorative level. My argument here is that the Italian policy of personalisation is clearly inspired by English experiences, while conferring new legitimacy to traditional personalist ideas in education. At the same time, the history of this idea and its unclear interpretation by scholars and policy makers render it a paper policy, quite distinct from actual school practice.

When Gentile (2007) maintains that the issue of personalisation in education appears as early as the '70s in Italian pedagogy, and has continued to be further developed over the past 30 years, he holds a broad view of personalisation, with individualisation or differentiation as its major, but not sole, ingredient. Clearly informed education politics drawing on personalisation were initiated (Law no. 53 in 2003, see Cattaneo, 2004). The reform debate was based on the theoretical assumption of a necessary dialogue and interaction between the curriculum, the dialectical order of knowledge (planning) and the adaptation of the curriculum to local needs and circumstances (personalisation) (Benzoni, 2004). The main innovations of this law were: the personalisation of study plans, the tutorial function, the laboratories and portfolio of competences (Zanniello, 2005).

The portfolio includes a sequence of learning experiences, of specific ability creation and development. It contains rubrics defining quality and the way that standards are to be reached. On standards, it is unclear as to whether they should be un-prescribed and subjectively defined, or if they should mediate between individual potential and the curriculum. A preliminary condition to realise personalised study plans is a flexible school organisation. This provides the opportunity for 'laboratories', or 'groups of pupils from the same class or from different classes, grouped by ability, i.e. capacity level and learning performance, or by the requirement to solve a specific problem, or in order to agree on the development of specific and common interests and passions' (Zanniello, 2005, p. 9).

The most relevant pedagogical tool in implementing the personalisation of education is personalised study plans, detailing all the learning units undertaken by each pupil. Anello (2005) considers that the Personalised Study Plan [PSP] may be developed at the end of the formative pathway, and not at the beginning. It is therefore erroneous in her view to assume that at the beginning of the school year teachers must create as many personalised plans as there are pupils in their classes. At the end of the year, a PSP may include some learning units common to all students and others which pertain only to some pupils.

In addition, PSP development should consider some specific requirements:

- the subject of the learning processes as persons in their personal and socioeconomic and cultural diversity;

- the minimum learning standards in both the general and specific aims of the learning process, as indicated by the National Indications for each grade;

- the sequence of the learning process and a timescale related to the initial levels of pupils who are to acquire certain abilities;

- modalities and tools of evaluation, both intermediary and final. 
From these comments on the policy directions and suggestions on the personalisation of education, one can assume certain characteristics of the Italian approach to personalisation. First of all, while it aims to put the personal dimension at the forefront through authentic assessment, as many scholars indicate, the policy documents are mostly functionally oriented. In point of fact, the specification of the types of laboratories ( 6 areas: IT, linguistics, expressive subjects, project based activities, sports activities) and the specific requirements that must be met in planning personalised study plans, indicate undeniable prescribed professionalism and the relevance of external standards. In this sense, Italian personalisation is in line with Fullan's conception that standards remain relevant and must be communicated to students in order to document real progress. Less comprehensible is the bureaucratic specification of the types of possible laboratories, all the more so against the background of decentralisation reform.

A second trait of Italian personalisation through PSP is the a posteriori nature of this strategy and pedagogical tool. A PSP, as the result of all the activities undertaken by a student as evaluated at the end of the year, is not a useful strategy and future oriented. The underlying vision of what personalised plans means is unfortunately based on a mechanistic vision of the whole class assemblage and individualised activities, specific group activities as backward-oriented. An evident reluctance to increase the teacher's workload with the task of developing personalised pathways render this policy completely ineffective. Italian scholars converge on the need to know each student individually in order to identify at any time during the school year their potentialities and limits, and thus to plan adequate pathways. A clearly bureaucratic, conservative conception of how personalisation might be implemented is at work.

A third relevant element refers to how laboratories might be organised. Policy documents list a series of mixed, homogeneous and interest-based grouping possibilities. However, the legislator should be well aware that in practice grouping by ability is the preferred solution by Italian teachers. In fact, when they opt for diversifying the dominant whole-class teaching, the most frequent alternative is grouping within the class by ability, not by task or interest preference. Undeniably, this strategy reproduces homogeneous groupings from the point of view of pupils' social and economic backgrounds. A form of in-class segregation, omnipresent alongside other out-of class forms is plainly visible.

In order to better understand the Italian case, it is useful to report Benadusi and Niceforo's (2010) argument. In their view, even some progressive initiatives like the full time school day or competence-based pedagogy turned out not to be as positive as expected, in terms of equity and excellence advancement. In fact, consistently these have been implemented in segregated ways and forms, that are 'exclusively for some types of schools, or for some kinds of pupils, e.g. those of lower social and economic classes and with more learning difficulties. Therefore, a homogeneity idea has been persistently at work and has come to suggest a dangerous form of division' (p. 42). It is therefore comprehensible that some:

innovative experiences that took place in Italian schools have mostly promoted heterogeneous grouping and pedagogies inspired by cooperative 
learning, deemed to promote at the same time and on equal bases the learning progress of the most competent students and of those with learning difficulties (Benadusi \& Niceforo, 2010, p. 43).

The politics of personalisation remained largely a paper exercise, but were slightly changed and even reversed only few years later. In fact, the Curriculum Guidelines of 2007 differ from those of 2004 in placing greater importance on the curricula instead of personalised study programmes. Moreover, the development of competences is much more related to teaching activities, while general learning objectives instead of analytically described learning objectives come to the forefront. As commented in the European Commission (2010) country report, these changes have been made 'in order to give more importance to school autonomy and to the professionalism of teachers in the planning of the curriculum' (p. 65). It is evident that the PSP and the 2003 innovations are in line with a more prescribed professionalism, in spite of their person-centred rhetoric.

The Italian policy discourse, research scholarship and concrete education politics reveal many of the paradoxes, theoretical shortcomings and implementation difficulties encountered by the issue of personalisation in other contexts. On the theoretical side, it is possible to identify different orientations and stances. In the first place, the left-wing authors, who see it as a continuation of the more traditional individualisation issue and the recent differentiation and heterogeneous groupings. In the second, the Catholic right-wing scholars, in line with the right-wing government policy and 2003 law on PSP, mainly influenced by a personalist and communitarian tradition, as well as by references to the English model and theories. In this case, a conceptual and political opposition between a Catholic oriented pedagogy supporting 'personalisation' and laity oriented pedagogy upholding 'individualisation' (Bertagna vs. Vertecchi) is at work. As Benadusi and Niceforo (2010) explain 'a new personalisation-oriented pedagogy of teaching and learning contrasts a more consolidated and less accentuated pluralist conception of individualisation' (p. 38).

Some major hallmarks of Italian personalisation come from its paradoxical policy development as an a posteriori exercise, in order not to overload teachers, its prescribed and bureaucratic orientation, as well as the confusing and problematic issue of how to organise laboratory innovations, given the traditional preference for homogeneous strategies and ability grouping. The Italian policy on personalisation was mainly a decorative reform. The message has not been communicated at all. When dealing with a student's difficulties, teachers mostly seek to agree a less demanding program with the parents. This is usually not a solution preferred by families and pupils, since it will have a negative influence upon their future school career and performance evaluation.

Although Italian schools are desperately in need of quality education in terms of inclusive practices for all diverse students - disabled, of immigrant origin, lower achievers - the policy reform apparently inspired by this principle failed to implement it effectively and communicate the need to the main school actors. Sterile, ideological debates on the difference with the individualisation issue 
abounded. In practical terms, the Italian policy of personalisation, partly inspired by English experiences, performed mainly a political function. It achieved new legitimacy and rhetorical visibility for traditional personalist ideas in education, while preserving old practices. The history of this idea and its unclear interpretation by scholars and policy makers render it a paper policy, quite distinct from actual school practice.

\section{CONCLUDING REMARKS}

In conclusion, I will draw on Paulston's $(1996,2003)$ notion of social cartography in order to present the reader with a more intuitive, albeit not rigidly stable, visual mapping of the conceptual positions of different scholars on the concept of personalisation. As Paulston and Lieberman (1996) state, "[t]hese perspectives are, of course, overlapping and not discrete. The point is that the utility of conceptual mapping as a secondary discourse style in the human sciences has been well demonstrated, yet, mostly ignored by educational researchers". (p. 40)

I will use the conceptual map as initially conceived by Paulston with the main macro-categories of humanist, functionalist, radical humanist and radical functionalist, and other internal lower level paradigms in order to achieve a better understanding, though fluid, of the conceptual positioning of contemporary scholars who endorse personalisation as a relevant pedagogical theory. The identification of the main positions in the field is in line with a conceptualisation of some of the main differences between these theories. I advance the idea that humanist and radical humanist orientations in the conceptualisation of personalisation uphold the practice of unscripted professionalism, rejecting the notion of standards. In contrast, functionalist positions require scripted professionalism and the usefulness of standards to produce personalisation in education.

In addition, I add two new dimensions, individualistically oriented versus mostly socially-oriented theories. These dimensions is a quite a relevant change to the original mapping of Paulston, and the problems of categorisation are in this case more relevant. Generally speaking, the humanistic orientations are in substance about "how social actors come to consciousness within social structures" as Paulston himself argues (p. 19), and are to be considered, though with some differences, mostly individualistic (Pearson \& Podeschi, 1999). In addition, functionalism is even more internally diversified, presenting both versions, societal and individualistic (Homans in Giddens \& Turner, 1987, p. 70). However, the humanist and functionalist notion of personalisation clearly place significant emphasis on the individual and not on the holistic/societal dimension. Radical positions, although still focused on the individual, have a societal change as their ultimate aim. However, this mapping of personalisation ideas that have emerged so far in the field should be considered as both provisional and fluid.

Therefore, when applying Paulston's model of comparative education paradigms (see Figure 1) to map theories of personalisation, a wide area of personalisation significance emerges: from humanist perspectives (Gardner), to 
radical humanist (Fielding) and functionalist (Fullan). In addition, it is possible to place there relevant dichotomies in Paulston's cartography:

- no learning outcomes standardisation \& assessment for learning vs. learning outcomes standardisation and standardised assessment; humanism vs. functionalism

- unscripted professionalism versus scripted professionalism - humanism vs. functionalism

- individualist vs. socially-oriented perspectives - classical humanist and functionalist orientations vs. the radical versions of these strands.

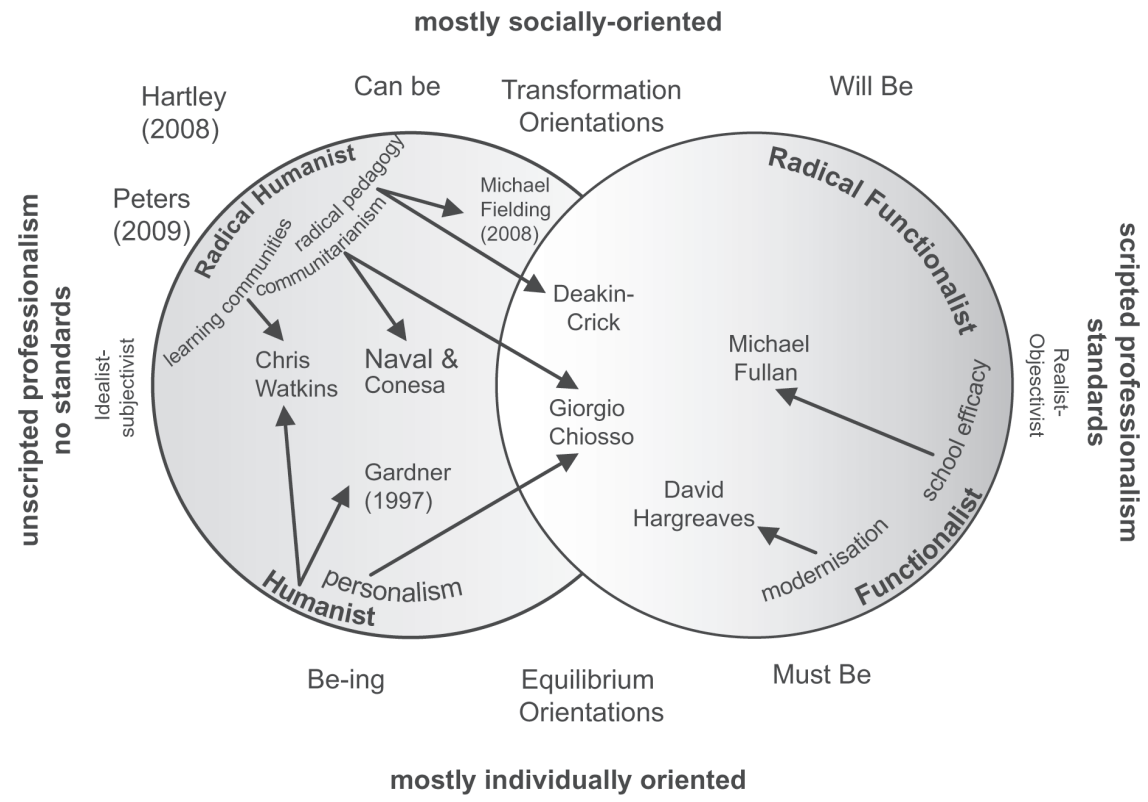

Figure 1.

The scholars work placed inside the Paulston's model is in line with the prevalent view on personalisation as meaningful teaching and learning theory, and particularly relevant in dealing with changes in contemporary schools. Those positions placed outside of the two diagrams (Peters, 2009; Hartley, 2007, Robertson, 2005) assess personalisation as merely a - molecular - governance idea, in line with current restructuring reforms of state administration worldwide. In this case, personalisation appears largely as an education policy lacking a proper pedagogical theory.

Some major findings of this volume can be summed up as follows. The first main question is whether personalisation is understood as a new version of individualisation - as appears to be the case of the state of Victoria in Australia or as a prominently socially-oriented policy. For some scholars, personalisation 
involves an individual knowledge of the student as a person and his/her curriculum empowered through recognition of the learner's voice. This is a necessary prerequisite in order to personalise the teaching and learning processes. At the same condition, those scholars warn against individualisation or differentiation seen as radically different from a socially embedded idea of person.

Another relevant issue is that for some scholars, personalisation might involve ability grouping and whole-class teaching (see for instance the Australian case). Personalisation does not always involve individualised teaching, but it makes space for the learner's voice and a deep knowledge of each learner in order to tailor personalised pathways. In addition, clear strategies might be combined in different circumstances. However, a speculative analysis must be completed with empirical evidence about what works with students most at risk to dropping out. In this context, ability grouping as a practical translation of a personalised idea of education seems a logically inconsistent approach. In fact, personalisation could be seen as a teaching and learning model, an efficient alternative to practices of student grouping and segregation inside schools and classrooms and to the prevalent practice of whole class teaching.

A third issue is whether personalisation might imply no standards regulation or quality assessment, as many scholars maintain. From a theoretical viewpoint, as revealed by the comparative tables of theoretical views and policies, I argue that personalisation is a relevant issue at stake if it keeps its promises to improve the condition of all learners and especially of those targeted groups. Otherwise, it would undoubtedly lose its appeal as a personally relevant and socially equitable strategy.

\section{REFERENCES}

Allport, F. H. (1924). Social psychology. Boston: Houghton Mifflin Company.

Anello, F. (2005). Personaliszare l'apprendimento. Obiettivi e fasi di elaborazione del percorso formativo. In A. La Marca (Ed.). Personaliszazione e apprendimento. Strumenti e competenze. [Personalisation and learning. Instruments and competences] (pp. 61-93). Roma: Armando Editore.

Benadusi, L., \& Niceforo, O. (2010). Obbligo scolastico o di istruzione. Alla ricerca dell'equità. [Compulsory schooling or instruction: striving for equity]. FGA Working Paper, no. 27. Turin: Fondazione Giovanni Agnelli. Retrieved from http://www.fga.it/uploads/media/L._Benadusi_O._ Niceforo_Obbligo_scolastico_o_di_istruzione___FGA_WP27.pdf

Bentley, T. \& Miller, R. (2006). Personalisation: Getting the questions right. In OECD (Ed). Personalising education. Paris: OECD.

Black, R. (2007). Crossing the bridge. Overcoming entrenched disadvantage through student-centred learning. The R.E. Ross Trust, Education Foundation. Retrieved from www.educationfoundation .org.au/Downloads/Research/RosBlackCrossingTheBridge.pdf.

Brint, S. (1998). Schools and societies. Thousand Oaks, CA: Pine Forge Press.

Benzoni, I. (2004). Portfoglio delle comptenze e processi di personaliszazione. [Portfolio of competences and processes of personalisation]. Azzano San Paolo: Junior.

Campbell, R. J., Robinson, W., Neelands, J., Hewston, R., \& Mazzoli, L. (2007). Personalised Learning: Ambiguities in Theory and Practice. British Journal of Educational Studies, 55(2), 135-154.

Centre for Applied Educational Research (2002). Middle Years Research and Development (MYRAD) Project Executive Summary February. A report to the learning \& teaching innovation division. 
Department of Education \& Training. Faculty of Education. Melbourne: The University of Melbourne.

Clarke, J. (2003). Changing systems to personalise learning. Introduction to the personalisation workshops. Providence, RI: The Education Alliance at Brown University.

Cole, P. (2001). Review of curriculum provision: An overview of interstate and international approaches to curriculum provision. Prepared for the Victorian Department of Education, Employment and Training. Melbourne: Author.

Courcier I. (2007). Teachers' perceptions of personalised learning. Evaluation and Research in Education, 20(2), 59-80.

Department for Education and Skills (DfES) (2004a). A national conversation about personalised learning. Nottingham: DfES.

Department for Education and Skills (DfES) (2004b). Ninestile school. Birmingham - Organising the school for personalised learning.

Ducette, J., Sewell, T., \& Poliner Shapiro, J. (1996). Diversity in education: problems and possibilities. In F. Murray (Ed.). The Teacher Educator's Handbook: Building a Knowledge Base for the Preparation of Teachers. San Francisco: Jossey Bass.

European Commission (2010). Organisation of the education system in Italy. Retrieved from: http:// eacea.ec.europa.eu/education/eurydice/documents/eurybase/eurybase full reports/IT EN.pdf

Fielding, M. (2008). Personalisation, Education and the Market. Soundings, 38, 56-69.

Fullan, M., Hill, P. V., \& Crévola, C. A. (2006). Breakthrough. Thousand Oaks, CA: Corwin Press

Gardner, H. (1997). Fostering diversity through personalised education: implications of a new understanding of human intelligence. Prospects, 26(3), 347-363.

Gentile M., (2007). Insegnare alla classe e personaliszare l'apprendimento. L'Educatore, 55(5), 13-16. Retrieved from http://try.iprase.tn.it/en/activities/studyAndResearch/download/INSEGNARE_ALLA_ CLASSE_E_PERSONALISZARE_APPRENDIMENTO.pdf

Grow-Maienza, J. (1996). Philosophical and structural perspectives in teacher education. In F. Murray (Ed.). The Teacher Educator's Handbook: Building a Knowledge Base for the Preparation of Teachers. San Francisco: Jossey Bass.

Hargreaves, D. (2006). Personalising Learning 6: The Final Gateway: School Design and Organisation. London: Specialist Schools and Academics Trust.

Hargreaves, D. (2005). Personalising learning - curriculum advice and guidance. London: Specialist Schools Trust.

Hartley, D. (2007). Personalisation: the emerging 'revised' code of education? Oxford Review of Education, 33(5), 629-642.

Homans, G. C. (1987). Behaviourism and after. In A. Giddens, \& J. H. Turner (Eds). Social theory today. (pp. 58-81). Oxford: Polity Press.

Hopkins, D. (2006). System Leadership for School Transformation. Presented as the Dean's Lecture, Faculty of Education. Melbourne: The University of Melbourne.

Keamy, K., Nicholas, H., Mahar, S., \& Herrick, C. (2007). Personalising education: from research to policy and practice. Melbourne: Education Policy and Research Division. Office for Education Policy and Innovation-Department of Education and Early Childhood Development.

Kelly, R. (2005). UK Government White Paper: higher standards, better schools for all. Department for Education and Skills (UK). Retrieved from www.standards.dfes.gov.uk/publications/schoolswhitepaper/

Leadbeater C. (2004). Personalisation through participation: a new script for public services. London: Demos.

Miliband, D. (2006). Choice and voice in personalised learning. In OECD (Ed). Personalising education. Paris: OECD.

National Association of Secondary Schools Principals (NASSP) (1996). Breaking Ranks: changing an American institution. Reston, VA: Author.

National Association of Secondary Schools Principals NASSP (2004). What the Research Shows: Breaking Ranks in Action. Reston, VA: Authors.

National Commission on Excellence in Education (1983). A nation at risk: The imperative for educational reform. Washington, D.C.: US Department of Education.

National High School Alliance. (2005). A call to action: Transforming high school for all youth. Washington, DC: Author.

OECD (2006). Personalising education. Paris: Author. 


\section{E. MINCU}

Paulston, R. (1996). Mapping Knowledge perspectives in studies of social and educational change. In R. C. Paulston, M. Liebman, \& J. Nicholson-Goodman (Eds). Mapping multiple perspectives. Research reports of the University of Pittsburgh. Social cartography project, 1993-1996. Pittsburgh, PA: University of Pittsburg.

Paulston, R. C., \& Liebman, M. (1996). The promise of a critical postmodern cartography. In R. C. Paulston, M. Liebman, \& J. Nicholson-Goodman (Eds). Mapping multiple perspectives. Research reports of the University of Pittsburgh. Social cartography project, 1993-1996. Pittsburgh, PA: University of Pittsburg.

Paulston, R. (2003). A spatial turn in comparative education? Constructing a social cartography of difference. In Schriewer, J. (Ed.). Discourse formation in comparative education. Frankfurrt: Peter Lang.

Pearson, E. M., \& Podeschi, R. L. (1999). Humanism and individualism: Maslow and his critics. Adult Education Ouarterly, 50(1), 41-55.

Peters, M. A. (2009). Personalisation, personalised learning and the reform of social policy: the prospect of molecular governance in the digitised society. Policy Futures in Education, 7(6), 615-627.

Pilar, K. (2007). Personalisation efforts and the relationship to school climate in select Michigan high schools. (Unpubluished Ph.D. thesis). Retrieved from https://dspace.emich.edu:8443/dspace/ bitstream/1970/514/2/diss EdD PilarKA.pdf.

Robertson, S. (2005). Re-imagining and re-scripting the future of education: global knowledge economy discourses and the challenge to education systems. Comparative Education, 41(2), 151-170.

Sizer, T. (1984). Horace's compromise: The dilemma of the American high school. Boston: Houghton Mifflin.

Task Force on Education and Young Adolescents. (1989). Turning Points: Preparing American youth for the 21st century. New York: Carnegie Corporation of New York.

Tomlinson, C. (1998). The differentiated classroom. Alexandria, VA: Association for Supervision and Curriculum Development.

Watkins, C. (2004). Classrooms as learning communities (Research Matters series No. 24). London: University of London Institute of Education: National School Improvement Network.

Watkins, C. (2005). Classrooms as learning communities: what's in it for schools. London: FalmerRoutledge.

Zanniello, G. (2005). Presentazione. In A. La Marca (Ed.). Personaliszazione e apprendimento. Strumenti e competenze. Roma: Armando Editore.

Yang, R. (2007). Comparing policies. In Bray, M., Adamson, B. \& Mason, M. (Eds.). Comparative Education Research. Approaches and methods. Comparative Education Research Centre. The University of Hong Kong. Hong Kong: Springer.

\section{Monica Mincu}

University of Torino 